\title{
O SENTIMENTO CONSTITUCIONAL BRASILEIRO EM MEIO À PANDEMIA
}

\section{COMO A ERA INFORMATIZADA REFORMULOU O DEBATE PÚBLICO E SUSCITOU DISCUSSÕES SOBRE PREDICADOS ESTATAIS DIANTE DA CALAMIDADE SANITÁRIA ATUAL?*}

\begin{abstract}
Sofia Seabra Fagundes de Q. Guimarães *
Resumo: Com a deflagração da epidemia de Covid-19 no mundo, os fenômenos circunscritos à era da conectividade adquiriram novos contornos e, consequentemente, demandam uma nova lente analítica para se pensar a legitimidade democrática, o Direito e a política. Estes três últimos elementos, por sua vez, estão interligados por um ponto nodal: o sentimento constitucional, visto como uma ferramenta capaz de ditar rumos para a reinvenção da vida pós-pandemia. Após estabelecer um diálogo entre diferentes expoentes que versaram sobre o fenômeno do sentimento constitucional, o artigo busca analisar criticamente - através de exemplos ocorridos na pandemia - a forma como os fóruns virtuais de discussão incorporam, em maior ou menor grau, princípios da Lei Maior. Além de auxiliar na compreensão da maneira pela qual a Constituição de 1988 se espraiou pela sociedade brasileira, as tessituras expostas almejam uma reflexão crítica acerca dos dilemas, dos desdobramentos e das repercussões sobre o futuro de uma sociedade cada vez mais inserida na economia dos dados, dos algoritmos e das redes. Mergulhada em um estado de crise, a ágora virtual passou a apresentar sintomas preocupantes de nossos tempos, como o discurso anticientífico e a desinformação. $O$ presente estudo representa um convite à compatibilização entre, de um lado, a Teoria Geral do Estado e a Filosofia Constitucional, e, de outro, a Revolução Tecnológica: sem dúvidas, entender as nuances do ativismo digital configura um dos maiores desafios das ciências contemporâneas.
\end{abstract}

Palavras-chave: Sentimento constitucional; Pandemia; Era digital; Direito; Democracia contemporânea.

\footnotetext{
* O esboço deste artigo foi produzido como trabalho final da disciplina de Direito Constitucional I na Graduação em Direito da Universidade do Estado do Rio de Janeiro (UERJ), Brasil. A disciplina foi ministrada pelos Professores Luís Roberto Barroso e Luna van Brussel Barroso, aos quais agradeço gentilmente pelas interlocuções e pela disponibilidade e, principalmente, por lançarem novas e ricas perspectivas a respeito do Direito Constitucional. Agradeço também a meu querido pai, Rogério Bonorino, por ter sido um interlocutor importante na análise final deste estudo: seus "pitacos" valiosos certamente contribuíram para o amadurecimento das ideias aqui dispostas. E, por fim, dedico este ensaio ao meu querido avô Eduardo Seabra Fagundes (in memorian), o eterno "Dico". Uma fração da bibliografia usada na construção deste texto está presente em alguns dos livros que o pertenceram. Hoje habitando a minha estante, tais obras, além de me proporcionarem uma imersão profunda e instigante no universo jurídico, também são uma forma de aplacar a saudade e de amadurecer o sentimento constitucional que passou de geração em geração.

** Graduanda em Direito pela Universidade do Estado do Rio de Janeiro (UERJ), Brasil. Estagiária na banca Ferro, Castro Neves, Daltro \& Gomide Advogados. ORCID: https://orcid.org/0000-0001-8691-1611. Contato: sofiaseabraf@gmail.com
} 


\title{
BRAZILIAN CONSTITUTIONAL SENTIMENT \\ IN THE MIDST OF THE PANDEMIC \\ HOW DOES THE DIGITAL AGE REFORMULATE PUBLIC DEBATE AND RAISE DISCUSSIONS ABOUT STATE ATTRIBUTES IN THE FACE OF THE CURRENT SANITARY CALAMITY?
}

\begin{abstract}
With the outbreak of the Covid-19 epidemic in the world, the phenomena circumscribed to the era of connectivity acquired new contours and, consequently, demand a new analytical lens to think about democratic legitimacy, Law and politics. These last three elements, in turn, are interconnected by a nodal point: the constitutional sentiment, seen as a tool capable of dictating directions for the reinvention of post-pandemic life. After establishing a dialogue between different authors who dealt with the phenomenon of constitutional sentiment, the article seeks to critically analyze - through examples that occurred in the pandemic - the way in which virtual discussion forums incorporate, to a greater or lesser degree, principles of the Major Law. In addition to helping to understand how the 1988 Constitution spread throughout Brazilian society, the text aims at a critical reflection on the dilemmas, developments and repercussions on the future of a society increasingly inserted in the data economy of datas, algorithms and networks. Plunged into a state of crisis, the virtual cosmos began to present worrying symptoms of our times, such as denial and misinformation. The present study represents an invitation to make compatible, on the one hand, the Theory of the State and Constitutional Philosophy, and, on the other, the Technological Revolution: undoubtedly, understanding the nuances of digital activism is one of the greatest challenges of contemporary science.
\end{abstract}

Keywords: Constitutional Sentiment; Pandemic; Digital Age; Law; Contemporary Democracy.

\section{EL SENTIMIENTO CONSTITUCIONAL BRASILEÑO EN MEDIO DE LA PANDEMIA ¿CÓMO LA ERA INFORMÁTICA REFORMULÓ EL DEBATE PÚBLICO Y SUSCITÓ DISCUSIONES SOBRE LOS ATRIBUTOS DEL ESTADO FRENTE A LA ACTUAL CALAMIDAD SANITARIA?}

Resumen: Con el estallido de la epidemia de Covid-19 en el mundo, los fenómenos circunscritos a la era de la conectividad adquirieron nuevos contornos y, en consecuencia, demandan una nueva lente analítica para pensar en la legitimidad democrática, el derecho y la política. Estos tres últimos elementos, a su vez, están interconectados por un punto nodal: el sentimiento constitucional, visto como una herramienta capaz de dictar rumbos para la reinvención de la vida post pandemia. Luego de establecer un diálogo entre diferentes exponentes que abordaron el fenómeno del sentimiento constitucional, el artículo busca analizar críticamente - a través de ejemplos ocurridos en la pandemia - la forma en que los foros virtuales de discusión incorporan, en mayor o menor grado, principios de la Ley Mayor. Además de ayudar a comprender la forma en que la Constitución de 1988 se extendió por la sociedad brasileña, el texto apunta a una reflexión crítica sobre los dilemas, desarrollos y repercusiones sobre el futuro de una sociedad cada vez más insertada en la economía de datos, algoritmos y redes. Sumido en un estado de crisis, el ágora virtual comenzó a presentar 
síntomas preocupantes de nuestro tiempo, como el discurso contra la ciencia y la desinformación. El presente estudio representa una invitación a compatibilizar, por un lado, la Teoría General del Estado y la Filosofía Constitucional, y, por otro, la Revolución Tecnológica: sin duda, comprender los matices del activismo digital es uno de los mayores desafíos de la ciencia contemporánea.

Palabras clave: Sentimiento Constitucional; Pandemia; Era digital; Derecho; Democracia contemporánea.

"A Constituição jurídica logra converter-se, ela mesma, em força ativa, que se assenta na natureza singular do presente."

KONRAD HESSE.

\section{Introdução}

A democracia consiste sobretudo em um exercício de escuta ${ }^{1}$. Mesmo discordantes, os interlocutores oferecem uma consideração recíproca, através do desprendimento de uma energia comunicativa que desague em um consenso ${ }^{2}$ mínimo e satisfatório entre as partes. No entanto, o regime democrático tem vivenciado uma fase em que a faculdade de escutar está cada vez menos aguçada e, em certa medida, mais rara.

Para além do refluxo virulento de ondas que reforçam o processo de erosão democrática $^{3}$ ao redor do mundo, a emergência da Revolução Tecnológica instaura um desafio sem precedentes: os fóruns de discussão virtual promovem, de um lado, um incremento no debate público, através da polifonia existente, e, de outro, um empobrecimento de discussões que deveriam fugir da superficialidade. Com a deflagração da pandemia de Covid-19 no mundo, cumpre indagar a maneira com que os fenômenos circunscritos à era da conectividade adquiriram novos contornos e, consequentemente,

\footnotetext{
${ }^{1}$ Segundo Javier Hervada, dentre as inclinações naturais do homem, está a tendência à comunicação. Das finalidades de tal tendência, derivam-se o dever de veracidade, o direito à boa reputação, dentre outras prerrogativas essenciais (HERVADA, Javier. O que é o direito? A moderna resposta do realismo jurídico. Tradução de Sandra Martha Dolinsky. 1.ed. São Paulo: WMF Ed. Martins Fontes, 2006, p. 151)

2 "Na teoria da ação comunicativa ou do agir comunicativo, o sistema social adquire a sua identidade a partir do consenso" (NASCIMENTO, Valéria Ribas do; MORAIS, José Luis Bolzan de. A cidadania e a Constituição: Uma necessária relação simbólica. Revista de Informação Legislativa, Brasília a. 44 n. 175 jul./set. 2007. p. 170.)

${ }^{3}$ Sobre o fenômeno da recessão democrática, observa-se: "Os exemplos foram se acumulando ao longo dos anos: Hungria, Polônia, Turquia, Rússia, Geórgia, Ucrânia, Filipinas, Venezuela, Nicarágua. Em todos esses casos, a erosão da democracia não se deu por golpe de Estado, sob as armas de algum general e seus comandados. Nos exemplos acima, o processo de subversão democrática se deu pelas mãos de presidentes e primeiros-ministros devidamente eleitos pelo voto popular." (BARROSO, Luís Roberto. Sem data venia: um olhar sobre o mundo e sobre o Brasil. 1. ed. Rio de Janeiro: História Real, 2020. p. 86.)
} 
demandaram uma nova lente analítica ${ }^{4}$ para se pensar a legitimidade democrática, o Direito e a política. Estes três elementos, por sua vez, são entrelaçados, em certo sentido, por um ponto nodal: o sentimento constitucional, fio condutor da discussão aqui empreendida.

Este pequeno ensaio pretende - vale lembrar, sem a intenção de esgotar as possibilidades interpretativas que rondam a temática - estabelecer um diálogo entre diferentes expoentes que versaram sobre o fenômeno do sentimento constitucional. Em seguida, será discutido como o debate público na esfera virtual brasileira abraça, em parte, os princípios constitucionais. A exposição também irá discorrer, oportunamente, sobre a conexão entre as manifestações expressas online e o debate acerca de um acontecer constitucional em meio a um estado de crise. Completando o itinerário, as considerações procuram iluminar - ainda que de forma incipiente - como a democracia, o Direito e a política terão de lidar com os dilemas futuros, sendo o sentimento constitucional uma ferramenta essencial na reinvenção da vida num mundo pós-pandêmico.

\section{As nuances do conceito de "sentimento constitucional"}

"É mais fácil se livrar de um piano do que de um sentimento"

ANA MARTINS MARQUES, O Livro das Semelhanças.

Em primeiro lugar, cabe esclarecer e, em alguma medida, fixar a noção de "sentimento constitucional". No fundo, não há uma definição cabal e unívoca que pretenda dar conta, de maneira totalizante, desse conceito complexo e multifacetado. Muitos são os autores que se debruçaram sobre a questão: mesmo que seja possível perceber um consenso mínimo entre os escritos, a noção em tela pode adquirir contornos peculiares, em que pese as especificidades do contexto político-institucional de cada tempo e lugar ${ }^{5}$.

Grosso modo, o "sentimento constitucional" pode ser definido como um sentir jurídico ínsito a uma espécie de "inconsciente coletivo" compartilhado por todos os cidadãos submetidos a uma Lei Maior. As formas de manifestação e de externalização desse traço do imaginário popular podem se dar, em virtude das circunstâncias, em maior ou menor

\footnotetext{
4 “(...) apenas com propostas que consigam articular bem teoria política com experiências concretas poderá se fornecer os subsídios necessários para que se aproveite o potencial que as novas relações interpessoais representam para a mudança nas instituições políticas." (MAGRANI, Eduardo. Democracia conectada: a internet como ferramenta de engajamento político-democrático. Curitiba: Juruá, 2014. 222p. Introdução de Pedro Abramovay.)

5 “(...) a compreensão de Constituição não deve se dar num espaço vazio, atemporal, justamente porque é o resultado das experiências históricas que se renovam (...)" (NASCIMENTO; MORAIS. A cidadania e a Constituição, cit., p. 169.)
} 
intensidade: no geral, momentos históricos marcantes acabam por afetar sobremaneira questões atinentes à "metafísica democrática", à filosofia constitucional e à psicologia social. No presente, o componente epidemiológico e o estágio de desenvolvimento tecnológico acrescentam-se como variáveis decisivas para o mapeamento do fenômeno. Sem embargo, diversos ramos do Direito - mormente o Constitucional ${ }^{6}$ - terão que incorporar estratégias para lidar com uma sociedade cada vez mais conectada, frente a um mundo pós-pandemia.

Para uma compreensão sólida acerca do assunto, o estabelecimento de um diálogo entre autores célebres faz-se oportuno. Uma seleção das considerações mais relevantes de estudiosos renomados pode promover a aproximação entre o sentimento constitucional - um conceito demasiadamente abstrato - e a realidade brasileira.

Para Pablo Lucas Verdú, o sentimento constitucional "supõe a implicação com o ordenamento jurídico e com a ideia de justiça que o inspira"7 . Ou seja, o liame jurídicopolítico estabelecido entre o povo e a sua respectiva Lei Fundamental possibilita que o convite ao cumprimento dos princípios constitucionais seja um traço indispensável da moral coletiva de um país. Com base nas leituras do autor espanhol, "o conceito de Constituição é completo quando, à sua intelecção teorética, une-se sua compreensão emocional através do sentimento que adere ao conceito ${ }^{8 "}$. Nessa senda, a interiorização emocional do Direito próprio e alheio à própria consciência ${ }^{9}$ simboliza o reconhecimento da ordem fundamental como elemento agregador na vivência diária do cidadão.

\footnotetext{
6 “(...) a mais importante instituição surgida no período moderno da doma do poder, graças à qual amadureceram as condições para o pleno desenvolvimento do Direito Público atual, é o Direito Constitucional, que veio apresentar um fundamento geral de valores jurídicos estatais, impositivos tanto para o próprio Estado, quanto para regrar as suas relações com a sociedade e mesmo entre as pessoas, qualificando, desse modo, uma etapa juspolítica evolutiva, a notável conquista do Estado de Direito." (MOREIRA NETO, Diogo de Figueiredo. O Direito Administrativo no Século XXI. Belo Horizonte: Fórum, 2018, p. 175.)

7 "O sentimento constitucional é expressão de uma cultura política assimilada e sentida pelas pessoas acerca dos principais alicerces jurídico-políticos de convivência, o que envolve realização de direitos fundamentais. (...) Existe uma relação intrínseca entre a Constituição, a cultura e os valores da sociedade, de maneira que o Texto Maior não pode ser visto apenas como uma pauta de regras desvinculada das influências do meio social." (NASCIMENTO; MORAIS. A cidadania e a Constituição, cit., p. 164.)

${ }^{8}$ VERDÚ, Pablo Lucas. O sentimento constitucional: aproximações ao estudo do sentir constitucional como modo de integração política. Tradução de Agassiz Almeida Filho. Rio de Janeiro: Forense, 2004. p. 74.

${ }^{9}$ Cf. Ibidem, p. 59.
} 
Ao recuperar os insights de Konrad Hesse ${ }^{10}$, Wallace Corbo consigna a existência de "um vínculo entre a sociedade e a Constituição ${ }^{11}$ que impulsione aquela no sentido de fazer valer e respeitar o conteúdo desta última."12. Ao que acrescenta: "A vontade da Constituição (...) é aquele fator presente na consciência geral que permite converter a Constituição em força ativa"13. Destarte, "ter e estar ${ }^{14}$ em Constituição" manifesta uma etapa crucial no reconhecimento ${ }^{15}$ da Lei Maior como cúspide incontestável da pirâmide normativa e como referencial institucional legítimo a partir do qual os indivíduos buscam adquirir autorrespeito ${ }^{16}$.

É evidente, porém, que a Constituição possui "uma função de propaganda e de educação política" ${ }^{\prime \prime 17}$. Nesse sentido, o professor Diogo de Figueiredo Moreira Neto destaca a construção incessante de um consenso legitimatório da sociedade, processo que passa, necessariamente, pela educação cívica para o exercício da cidadania ${ }^{18}$. De certo modo, a "função pedagógica" da Carta Constitucional clama por um engajamento social ativo, através de um povo comprometido - consciente ou inconscientemente - com as disposições

\footnotetext{
${ }^{10}$ Sobre o pensamento de Konrad Hesse e a sua contribuição para a concepção moderna de Constituição: "Na concepção de Hesse, a realização da Constituição importa na capacidade de operar na vida política, nas circunstâncias da situação histórica e, especialmente, na vontade de Constituição, que procede de três fatores: da consciência da necessidade e do valor específico de uma ordem objetiva e normativa que afaste o arbítrio; da convicção de que esta ordem constituída é mais do que uma ordem legitimada pelos fatos e que necessita estar em constante processo de legitimação, e da consciência de que se trata de uma ordem que não logra ser eficaz sem o concurso da vontade humana, principalmente das pessoas envolvidas no processo constitucional, isto é, de todos os partícipes da vida constitucional.” (VIEIRA, Iacyr de Aguilar. A essência da Constituição no pensamento de Lassalle e de Konrad Hesse. Revista de Informação Legislativa. Brasília a. 35 n. 139 jul./set. 1998, p. 72.)

11 "Com Hesse, no entanto, é possível também afirmar que a Constituição se molda à realidade social em constante mudança (...)." (CORBO, Wallace. Filosofia Constitucional e Teoria do Reconhecimento: entre o Direito Constitucional ao Reconhecimento e o Constitucionalismo do Reconhecimento. Revista da Faculdade de Direito do Sul de Minas, Pouso Alegre, v. 34, n. 1: 1-35, jan./jun. 2018.) A partir dessa afirmação, o conceito de mutação constitucional vem à baila: significa, pois, o "mecanismo que permite a transformação do sentido e do alcance de normas da Constituição, sem que se opere, no entanto, qualquer modificação do seu texto. A mutação está associada à plasticidade de que são dotadas inúmeras normas constitucionais." (BARROSO, Luís Roberto. Curso de Direito Constitucional Contemporâneo. 9. ed. São Paulo: Saraiva Educação, 2020, p. 576)

${ }^{12}$ CORBO. Filosofia Constitucional e Teoria do Reconhecimento, cit., p. 25.

${ }^{13}$ Ibidem, p. 24.

${ }^{14}$ Sobre "ter e estar em Constituição", observar: "Enquanto por ter deve ser entendida a vontade de normatizar e institucionalizar juridicamente a lei fundamental, estar em Constituição consiste em buscar a adesão ao ordenamento." (VIEIRA, Andréa Maria dos Santos Santana. A importância do sentimento constitucional como substrato para a construção da cidadania no Brasil. Derecho y Cambio Social. n. 31.01 de jan. de 2013.)

${ }^{15}$ Wallace Corbo trabalha as bases de um constitucionalismo do reconhecimento: "não basta dizer que a Constituição é um espaço de luta por reconhecimento - é preciso também compreender como a própria Constituição contribui para esta luta cotidiana e plural." (CORBO. Filosofia Constitucional e Teoria do Reconhecimento, cit., p. 24.)

${ }^{16}$ Idem.

${ }^{17}$ VERGOTTINI, Giuseppe de. 2004: verbete "Constituição". In: Norberto BOBBIO, Nicola MATTEUCCI \& Gianfranco PASQUINO: Dicionário de Política, UnB, Brasília. p. 259.

${ }^{18} C f$. MOREIRA NETO. O Direito Administrativo no Século XXI. cit., p. 175.
} 
normativas basilares que habitam o universo da cidadania: "sem o reconhecimento ético da identidade cidadã não há a propagação suficiente do sentimento constitucional"19.

Nesse ínterim, cabe ressaltar um aspecto transcendente das normas constitucionais, destacado por Fábio de Sousa Coutinho: "uma Constituição não é tampouco uma obra jurídica e doutoral, um compêndio de teses uniformemente desenvolvidas, mas um documento plástico de sabedoria e experiência, com um caráter pragmático e normativo ${ }^{20 "}$. Em outros termos, a sapiência constitucional está devidamente plasmada nas forças políticas e sociais $^{21}$ que colorem a sociedade, desde o momento de feitura do diploma até a sua conformação normativa atual.

No bojo da teoria constitucional brasileira e na esteira do neoconstitucionalismo, Luís Roberto Barroso celebra o progresso do sentimento constitucional no país, sobretudo após a superveniência da Constituição Cidadã de 1988: "Trata-se de um sentimento ${ }^{22}$ ainda tímido, mas real e sincero, de maior respeito pela Lei Maior, a despeito da volubilidade de seu texto." Ao que complementa: "No Brasil, o florescimento de um sentimento constitucional proporcionou-nos o mais longo período de estabilidade institucional desde a Independência (...)". Certamente, quanto maior a identificação popular com os valores de

\footnotetext{
${ }^{19}$ Cf. MOREIRA, Nelson Camatta. Fundamentos de uma teoria da constituição dirigente. Santa Catarina: Conceito, 2010, p. 201-202.

${ }^{20} \mathrm{Na}$ mesma direção, Luís Roberto Barroso escreve: "Uma Constituição não é só técnica. Tem de haver, por trás dela, a capacidade de simbolizar conquistas e de mobilizar o imaginário das pessoas para novos avanços." BARROSO, Luís Roberto. Neoconstitucionalismo e constitucionalização do Direito (O triunfo tardio do direito constitucional no Brasil). Revista de Direito Administrativo, v. 240, p. 1-42, 1 abr. 2005.

Aliás, a potência simbólica de uma Constituição mostra-se evidente sobretudo nos sistemas de common law. Nesse sentido, afirma Fábio de Sousa Coutinho: "Justifica-se, para nós, brasileiros, o conhecimento da Constituição Britânica, fonte inegável do nosso constitucionalismo, quer por injunções históricas e ideológicodoutrinárias, quer por uma concreta articulação positiva. Havendo transcendido, pela universalidade de seus postulados, a órbita originária de um Estatuto Nacional, passou a ser patrimônio do Ocidente, em substancial proporção." Podemos estabelecer, ainda, um paralelo entre "sentimento constitucional" e "constitucional morality of the day". Este último conceito foi apresentado pelo professor Dicey, um exímio estudioso do papel das "conventions" no direito britânico. (COUTINHO, Fábio de Sousa. Leituras de Direito Político. 1. ed. Brasília: Thesaurus, 2004. 227 p. 37-40; 51-52)

${ }^{21}$ Vergottini discorre sobre o "papel desempenhado pelas forças políticas na fixação dos princípios organizativos e funcionais basilares para a vida de um ordenamento": “(...) há uma clara reavaliação do papel exercido pela realidade social, não mais confinada no pré-jurídico. O elemento social do Estado se apresenta como já ordenado em torno a um núcleo de princípios que contribuem para que ele adquira uma configuração política própria." (VERGOTTINI. Dicionário de Política, cit., p. 259)

22 "O Direito, como forma de expressão humana, envolve criação, sentimento, estilo. (...) Também o Direito ou, sobretudo o Direito - está no domínio dos sentimentos e das paixões." (BARROSO, Luís Roberto. Direito e Paixão. Revista da Faculdade de Direito da Universidade do Estado do Rio de Janeiro. n. 2, p. 321-338, 1994.)

Sobre a ligação do sentimento com o discurso jurídico: “(...) não é mais possível separar o ser humano do universo jurídico, sob pena de cada qual permanecer incompleto. (...) O sentimento encontra-se constantemente interligado ao atuar humano. Ainda que não integre o discurso jurídico enquanto foco central de consciência, atuará ao menos como pano de fundo. (...)" (VIEIRA. A importância do sentimento constitucional como substrato para a construção da cidadania no Brasil, cit., p. 2.)
} 
seu diploma constitucional, maiores as chances de perpetuação do projeto político pretendido e, por conseguinte, maior será o grau de efetividade das instituições ${ }^{23}$. Se o Constitucionalismo Democrático ${ }^{24}$ representou a ideologia vitoriosa do século XX, o exemplo da Magna Carta de 1988 demonstra o êxito na imersão democrática a que o Brasil se propôs, na tentativa de aplacar as feridas e os traumas de um período sombrio de ditadura militar.

2.1. Uma proposta de interpretação do "sentimento constitucional” à luz de Kant

"Como presença consciente no mundo, não posso escapar à responsabilidade ética no meu mover-me no mundo. " PAUlo FreIRE, Pedagogia da Autonomia.

Em verdade, qualquer estudo que venha a tangenciar uma questão concernente ao Estado deve remontar ao plano de sua justificação, de modo a resgatar as mentes pioneiras nas considerações filosóficas responsáveis pelo fortalecimento das sociedades políticas. Nesse sentido, vale propor uma incursão - ainda que singela - no ramo da Teoria Geral do Estado e, mais especificamente, na obra de $\mathrm{Kant}^{25}$.

Na aplicação do imperativo categórico à sua teoria política, o autor de "A Metafísica dos Costumes" defende que o contrato social - decorrente da razão humana - seria válido por si mesmo, uma vez que consubstancia, de alguma maneira, os imperativos categóricos dos integrantes da ordem social. Logo, é importante salientar que a moralidade intrínseca às ações e às escolhas humanas é ratificada por um "senso de dever" de cada sujeito. Em outras palavras, "fazer a coisa certa pela razão certa" suscita um valor moral caro ao agir humano.

Diante do exposto, vale estabelecer um paralelo entre o que Kant convencionou chamar de "sense of duty" - isto é, o agir com o senso de dever - e a noção de "sentimento constitucional”. Uma equiparação entre os dois conceitos permite vislumbrar uma primeira

\footnotetext{
23 “Destaca Luís Roberto Barroso que a efetividade da Constituição depende da "cristalização de um sentimento constitucional, resultado último do entranhamento da Lei Maior na vivência diária dos cidadãos". (Ibidem, p. 7.)

24 "Häberle refere que o arquétipo de Constituição Democrática compõe-se de elementos reais e ideais, estatais e sociais, localizados no seio do Estado Constitucional e que seriam a dignidade humana; a soberania popular; a Constituição como pacto; o princípio da divisão dos poderes; o Estado de Direito e o Estado Social de Direito.” (NASCIMENTO; MORAIS. A cidadania e a Constituição, cit., p. 168.)

${ }^{25}$ Sobre o conceito de sociedade justa à luz de Kant: "Uma sociedade justa é, segundo este procedimentalismo de matriz kantiana, aquela em que as pessoas podem participar politicamente, interferir de maneira igualitária no processo de tomada de decisões coletivas e, sem prejuízo disso, desenvolver suas concepções de boa-vida sem a interferência externa estatal." (CORBO. Filosofia Constitucional e Teoria do Reconhecimento, cit., p. 9.)
} 
conclusão: o sentimento constitucional poderia ser interpretado como um devir do sujeito para com a Carta Política a que se submete. Ou seja, na tentativa de espraiar o sentimento constitucional nas suas ações, o indivíduo - estimulado pela coletividade em que está inserido - incorpora para si o escopo axiológico presente na Carta, abraçando os princípios constitucionais que passam a estar coadunados com sua ética particular e cívica. Noutros termos, uma das etapas da depuração moral do sujeito político inclui o fomento a "atitudes subjetivas e objetivas dos cidadãos em conjunto com os órgãos estatais" ${ }^{26}$. As ponderações expostas a partir das contribuições kantianas devem compor o pano de fundo das discussões a serem tratadas nos próximos tópicos, uma vez que a teoria política representa um instrumento potente de análise crítica da realidade complexa dos nossos dias.

\section{A força e a fraqueza do sentimento constitucional na Web brasileira: os}

\section{efeitos da conectividade sobre a democracia, o direito e a política frente à pandemia}

De acordo com Eduardo Magrani, "a internet é uma ferramenta para promoção do desenvolvimento em diversas frentes", sendo o aprofundamento da democracia uma das suas mais notáveis consequências ${ }^{27}$. O autor de "Democracia conectada" aponta efeitos chaves observados a partir da inclusão digital, quer sejam: (i) melhoria da transparência do processo político $^{28}$; (ii) facilitação da participação ativa em processos políticos; e (iii) melhoria da qualidade da formação de opinião pública ${ }^{29}$, mediante a abertura de novos espaços de informação e deliberação.

Ainda que não possamos descartar o fosso tecnológico existente na população brasileira, dados coletados em 2019 pelo Instituto Brasileiro de Geografia e Estatística (IBGE) mostraram que a utilização da internet em qualquer local cresceu de 74,7\% - obtidos na pesquisa anterior - para 78,3\%. Apesar de tais estatísticas não ilustrarem o período

\footnotetext{
${ }^{26}$ NASCIMENTO; MORAIS. A cidadania e a Constituição, cit., p. 164.

${ }^{27}$ MAGRANI. Democracia conectada, cit., p. 21.

28 “A difusão do acesso à internet gerou a expectativa de mais participação política, melhor governança e maior accountability dos governantes em geral. Imaginou-se que no mundo interconectado por computadores seria possível a criação de uma abrangente esfera pública digital capaz de viabilizar o exercício da democracia deliberativa, fundada num debate público amplo entre pessoas livres e iguais, com oferecimento de razões e prevalência do melhor argumento.” (BARROSO. Sem data venia, cit., p. 89.)

${ }^{29}$ Para uma compreensão mais aprofundada do conceito de "esfera pública", Sérgio Costa a define como "a arena viva e dinâmica na qual o permanente processo de construção, desconstrução e reconstrução discursiva e simbólica da nação tem lugar”. (MAGRANI. Democracia conectada, cit., p. 22, 31.)
} 
pandêmico, o crescimento do acesso à rede mundial de computadores registra sempre um aumento interessante, como afirmou ao Estado de Minas a especialista Fernanda Gerken ${ }^{30}$.

No despontar da e-democracia ${ }^{31}$, a emergência da pandemia de Covid-19 acirrou ainda mais os ânimos em torno do debate público. Em razão do isolamento social, a arena virtual passou a ser a única maneira concebível de manifestação. A internet proporcionou, mesmo diante de uma calamidade sem precedentes, que a ágora fosse transportada para dentro de casa. Enquanto uns fizeram uso legítimo dessa oportunidade comunicativa e impulsionaram a discussão de pautas de utilidade pública - sobretudo a partir do reforço quanto à necessidade de contenção do vírus - , outros usuários desvirtuaram as diretrizes de uma Web que se pretende plural e democrática. Aqueles que se comportaram de forma errática dispensaram, na maior parte do tempo, qualquer noção de civilidade. Como essas duas reações contrárias evidenciam, a um só tempo, a ausência e a presença do sentimento constitucional na internet?

Recuperando os ensinamentos de Verdú, pode-se dizer que “(...) o sentimento jurídico brota de uma comoção da alma que normalmente contém momentos de prazer e de desgosto" 32 . No primeiro caso, observa-se uma adesão e uma sintonia com o ordenamento, através de um respeito espontâneo e vívido aos valores supraestatais. A contrario sensu, a segunda reação evidencia um distanciamento em relação ao tecido normativo "em virtude do desgosto por ele proporcionado, seja pela injúria que lança sobre o afetado ou sobre os seus próximos (...), seja porque se considera (...) que ele é injusto se comparado ao ordenamento jurídico ideal imaginado" "33. Nesse sentido, o binômio prazer/desgosto, exposto pelo autor espanhol, impõe-se no jogo de xadrez virtual brasileiro. O compartilhamento de informações vive o seguinte dilema: como a democracia e o sentimento constitucional

\footnotetext{
${ }^{30}$ Em 2019, dados do IBGE mostraram que a utilização da internet em qualquer local cresceu de $74,7 \%$ para $78,3 \%$ no geral. Apesar de os dados não ilustrarem o período pandêmico, o crescimento de acesso à internet registra um crescimento interessante. (MAYARA, Jéssica. Brasileiros têm mais acesso à internet, TV e smartphone; confira. Estado de Minas.)

31 "Também chamada de "ciberdemocracia" ou "democracia eletrônica". Entende-se por e-democracia o engajamento através de meios eletrônicos de comunicação que habilite e/ou auxilie cidadãos em seus esforços para interagirem politicamente, como: (i) melhorar a qualidade da formação de opinião por meio da abertura de novos espaços de informação e deliberação online; (ii) facilitar o envolvimento direto e a participação dos cidadãos nas decisões e processos políticos; e (iii) melhorar a transparência e accountability do poder público." (MAGRANI. Democracia conectada, cit., p. 21.)

${ }^{32}$ VERDÚ. O sentimento constitucional, cit., p. 56. O "desgosto" a que Verdú se refere representa um aspecto importante da política brasileira. A partir das Jornadas de Junho de 2013, o descontentamento foi, pouco a pouco, tomando uma forma amarga. Passando pelo impeachment da presidente Dilma de 2016, o "desgosto" em relação ao ordenamento teve seu ápice no cenário eleitoral de 2018, situação na qual muitos dos costumes democráticos foram amplamente deixados de lado, em nome de ideologias e de fanatismos.

${ }^{33}$ Ibidem, p. 56.
} 
podem se enquadrar minimamente em um terreno virtual cada vez mais vasto e, ao mesmo tempo, cada vez mais inóspito?

Transpondo a teoria em análise para a realidade, é possível afirmar que o ativismo digital no Brasil comportou, no mesmo macrocosmo virtual, tanto manifestações saudáveis à democracia quanto discursos contraproducentes ao debate público. Nos tópicos a seguir, a análise - acompanhada da citação de exemplos concretos ocorridos na pandemia - irá se desdobrar em dois momentos: em primeiro lugar, a discussão volta-se aos cenários hostis e perigosos do ponto de vista democrático; em seguida, a abordagem ressalta a força das narrativas que cultivaram, exitosamente, o respeito a direitos fundamentais.

3.1. O desestímulo ao sentimento constitucional promovido por discursos enviesados

"Uma palavra

deve-se pagar

com outra palavra

não necessariamente do mesmo tamanho"

ANA MARTINS MARQues, Senha e Contrassenha.

Hoje em dia, debruçar afetos políticos sobre o teclado muitas vezes não pressupõe uma etapa de ação contundente do superego. Algumas falas e comentários carecem de um respeito mínimo à ética democrática e, assim, os atos de "postar" e "compartilhar" acabam, por vezes, solapando valiosas virtudes do Estado de Direito. Nesse ínterim, a liberdade de expressão ${ }^{34}$ entra em rota de colisão com a salvaguarda de um núcleo fundamental da dignidade de todos os usuários.

Antes de analisar propriamente os contornos das manifestações que atentam contra princípios basilares do Estado Democrático, deve-se ter em mente a íntima relação entre o "desgosto" frente ao sentimento constitucional e o fortalecimento do ciber populismo ${ }^{35}$, um

\footnotetext{
34 “Agora, é preciso conceber uma teoria da liberdade de expressão desenhada não para um mundo de escassez de informação, mas de escassez de atenção: um mundo em que não é possível conhecer toda a informação disponível e o livre mercado de ideias não leva mais à depuração da verdade." (BARROSO, Luna Van Brussel. Luna van Brussel Barroso: A democracia e a liberdade de expressão | Fumus boni iuris - O Globo.)

35 "Deparamo-nos (...) face a um curto-circuito entre Web, aversão aos especialistas, valorização do autodidatismo e emergência de movimentos políticos produtores de storytelling à medida dos ressentimentos e dos estereótipos eleitoralmente mais rentáveis. Podemos então definir tal cruzamento entre imediatismo digital e imediatismo populista, como a origem do ciberpopulismo ou digital populism (Santoro, 2013; Khosravi Nick, 2018)." (BALDI, Vania. A construção viral da realidade: ciberpopulismos e polarização dos públicos em rede. Observatório (OBS) Special Issue, (2018), 004-020. p. 8.)
} 
sintoma potente da escalada da recessão democrática ${ }^{36}$. Marcado historicamente pela "manipulação dos medos e necessidades da população por líderes carismáticos"37-38, o populismo acrescentou elementos na sua expressão contemporânea, a saber: "o uso das redes sociais para comunicação direta com o povo"39-40. A ausência de mediação ${ }^{41}$ de veículos tradicionais fez da internet um terreno propício para a propagação de ideias concordes com um projeto próprio de esgarçamento da relação com as instituições políticas: "Nas palavras de Ming-Sung, "se beneficiando da democracia instantânea induzida pela tecnologia, o novo populismo apresenta uma política alternativa que busca substituir a complexidade constitucional por uma simplicidade anti-institucional ${ }^{42}$."

É inegável, porém, que o populismo digital ${ }^{43}$ está estribado em mecanismos ostensivos de propaganda, graças à apropriação das novas tecnologias. Essa conduta característica acaba gerando uma nova atmosfera cognitiva e uma nova gramática cultural ${ }^{44}$, marcada pela irrealidade e pelo anti-intelectualismo. Na pandemia de Covid-19, o ataque aos árbitros neutros partícipes do jogo democrático permaneceu como uma constante nos

\footnotetext{
36 “(...) o processo de erosão democrática recente decorre de atitudes e escolhas políticas incrementais que, se formalmente legítimas quando individualmente consideradas, resultam na violação ao espírito constitucional e em restrições à liberdade e aos direitos fundamentais quando cumuladas." (BARROSO, Luna Van Brussel. Recessão democrática, populismo e um papel possivel para as cortes constitucionais. Mimeografado, 2019, p. 6.)

${ }^{37}$ Nessa direção, escreve Miguel Seabra Fagundes: "O carisma pessoal também aparece como fonte do poder, a manifestar-se, principalmente, quando, nos momentos críticos da vida dos povos, surgem salvadores dotados de capacidade incomum de ousar e fazer ao encontro das aspirações e necessidades populares." (XI ENCONTRO DE ADVOGADOS, 1982, Garanhuns, Pernambuco. A Legitimidade do Poder Público na Experiência Brasileira. 30p.)

${ }^{38}$ BARROSO. Sem data venia, cit., p. 87.

39 “(...) o mandato é exercido pelo líder eleito de forma quase plebiscitária e hiperresponsiva à vontade de uma maioria apresentada como a "dona da verdade". Esses fatores minam as estruturas da democracia e o lapso temporal imprescindível para a tomada de decisões políticas. Assim, permite que atores institucionais, atuando em nome do povo, desconsiderem regras procedimentais fundamentais para a subsistência de uma democracia constitucional." (BARROSO. Recessão democrática, populismo e um papel possível para as cortes constitucionais, cit., p. 14.)

${ }^{40}$ BARROSO. Sem data venia, cit., p. 87.

41 "A desintermediação proporcionada pelas redes sociais implicou, de facto, a tendência para nivelar a perceção das diferenças entre opiniões individuais e conhecimentos objetivos, desafiando aquele afastamento entre factos e interpretações que reforça um tipo de credulidade falaciosa em notícias sempre mais distorcidas e alteradas." (BALDI. A construção viral da realidade, cit., p. 8.)

${ }^{42}$ BARROSO. Recessão democrática, populismo e um papel possível para as cortes constitucionais, cit., p. 14.

43 "Un enojo con la política tradicional y un miedo que se traduce en activismo digital: los sujetos se radicalizan desde la virtualidad y convierten el desencanto en expresiones políticas de extrema derecha, que parece ser el único espacio político desde donde se permite cuestionar la realidad. Internet aparece como el mejor medio para expresar ese desencanto, y las redes sociales, como la vía ideal para propagarlo.” (¿Qué pasa con la extrema derecha online? | Nueva Sociedad. Nueva Sociedad | Democracia y política en América Latina.)

44 “(...) merece a nossa melhor atenção o estabelecimento de uma nova gramática cultural diversamente incorporada nos vários comportamentos info-comunicacionais.” (BALDI. A construção viral da realidade, cit., p. 8.)
} 
discursos de tal espectro político. Contudo, a narrativa anticiência despontou como uma pauta recorrente, na forma do desincentivo ao uso de máscaras, da defesa de tratamentos sem comprovação científica, do descrédito em relação à vacina e do desrespeito às medidas sanitárias. Mas, afinal, como os traços mencionados emergiram na esfera do debate público virtual?

Paradoxalmente, a faceta do "desgosto" frente ao sentimento constitucional partiu sobretudo de pessoas que compunham os quadros dos órgãos representativos estatais, a exemplo do que ocorreu com o deputado Daniel Silveira. O caso do parlamentar chegou ao Supremo Tribunal Federal ${ }^{45}$ : Silveira ${ }^{46}$ veiculou um vídeo nas suas redes sociais em que, além de atacar e ameaçar ministros da Corte, evocou a figura do Ato Institucional $\mathrm{n}^{\mathrm{o}} 5$, dispositivo usado na repressão e na perseguição durante o regime militar. Na tentativa de construção falaciosa de um passado mítico e idealizado, Silveira parecia querer "girar a roda da História para trás", minando qualquer resquício de etiqueta democrática.

Quanto ao discurso anticientifista ${ }^{47}$, vale citar o caso da exclusão de um vídeo veiculado nas redes da deputada Bia Kicis. O site "Youtube" retirou do $\mathrm{ar}^{48}$ postagem

\footnotetext{
45 "Essa semana [30 de abril de 2021], o Supremo Tribunal Federal votou, por unanimidade, para receber denúncia contra Deputado Federal que dirigiu ataques à Suprema Corte e defendeu atos antidemocráticos." (BARROSO. Luna van Brussel Barroso: A democracia e a liberdade de expressão | Fumus boni iuris, op. cit.) 46 “(...) a declaração do deputado Daniel Silveira tem o real e permanente impacto de motivar seguidores a realizarem a barbárie que ele prega, atacando os ministros que ele citou. $O$ fato de ele não o fazer explicitamente (...) não desnatura o impacto e a indução ao ódio e violência contida na declaração por ele proferida. Ou seja, o discurso do ódio, mesmo não clamando por uma ação específica, é elemento indutor do ato de violência." (ADAMS, Luís Inácio. O discurso do ódio e a liberdade de expressão II: o caso do deputado Daniel Silveira. Consultor Jurídico.)

47 “A disseminação contínua da epidemia do coronavírus acabou desencadeando, também, certas epidemias de vírus ideológicos que estavam adormecidos em nossas sociedades: fake news, teorias da conspiração, paranoicas e explosões de racismo (ZIZEK, 2020a)". (TEIXEIRA, João Paulo Allain; SPAREMBERGER, Raquel Fabiana Lopes. Da Sociedade do Cansaço à Sociedade da Vigilância: entre utopias e distopias, o direito à privacidade no contexto pós-pandemia. In: MELO, Ezilda; BORGES, Lize; SERAU JR., Marco Aurélio (Orgs.). Covid-19 e Direito Brasileiro: mudanças e impactos. 1. ed. São Paulo: Tirant lo Branch, 2020, p. 44) ${ }^{48}$ AGÊNCIA ESTADO. YouTube remove vídeo de deputada Bia Kicis por desinformar sobre covid-19. Brasil. A posição combativa e belicosa da extrema direita nas redes sociais vem apresentando desdobramentos peculiares no Brasil de hoje. O governo Bolsonaro - cuja estratégia de campanha teve nas redes sociais um palanque decisivo para a sua vitória eleitoral - passa a usar dos artifícios mais apelativos para contornar limites estabelecidos: no país da Lei de Acesso à Informação, a atual gestão não se demonstra simpática a entraves que atentem contra as suas vontades políticas. Nesse ponto, v. VARGAS, Matheus. Bolsonaro prepara decreto, considerado ilegal, para limitar retirada de posts e perfis das redes sociais. Folha de S. Paulo. Para uma análise crítica sobre a posição do Planalto, v. Especialistas questionam tentativa de dificultar retirada de conteúdo das redes. Consultor Jurídico.
} 
realizada no canal da parlamentar ${ }^{49}$, em virtude da clara desinformação ${ }^{50}$ quanto à pandemia de Covid-19. Investigada por atos antidemocráticos e reivindicação de pleitos inconstitucionais $^{51}$, a atual presidente da Comissão de Constituição e Justiça (CCJ) da Câmara dos Deputados tornou-se notadamente conhecida por pulverizar posicionamentos contra o uso de máscaras e as medidas de isolamento. Ao promover um ambiente virtual insalubre, postagens desse cunho vão de encontro à garantia do direito à saúde ${ }^{52}$ da população, contribuindo para tornar turvas informações caras à preservação da vida.

A partir dos exemplos pregressos, vale contextualizar a liberdade de expressão com o sentimento constitucional. Nas ocasiões já mencionadas, os discursos veiculados nas redes sociais atacaram frontalmente a democracia. Isto é, posturas semelhantes às dos dois deputados supramencionados não encontram guarida na garantia fundamental em tela. Como devemos (e se devemos) reinterpretar o direito fundamental de expressão para endereçar os novos desafios? O visível descomprometimento com o projeto democrático - um empreendimento que supõe, em si mesmo, a ideia de um autogoverno coletivo - evidencia, por sua vez, a atrofia do sentimento constitucional: aqueles que invocam a liberdade de expressão em nome de um posicionamento à revelia do interesse público posicionam-se de modo contrário a princípios tão caros ao processo civilizatório e esculpidos com muita luta na história constitucional. Em que pese seu caráter fundamental, a liberdade de expressão valorada no cotejo com outros princípios fundamentais - não pode sobrepujá-los nem tampouco aniquilá-los, o que caracterizaria um exercício abusivo de tal direito.

A própria existência de tais cenários preocupantes aqui expostos permite a seguinte reflexão: o sentimento constitucional, quando carecido de estímulo, esmorece. A despeito da ocorrência - infelizmente comum - de discursos contrários ao espírito democrático, o otimismo não deve arrefecer: há, indubitavelmente, um vento transformador que paira sobre

\footnotetext{
${ }^{49}$ Sobre pensar a teoria da liberdade de expressão em conjunto com a atuação de agentes públicos: “(...) devese cogitar da legitimidade de uma teoria da liberdade de expressão que atribua a autoridades públicas, no exercício de suas funções e em campanhas políticas, um ônus maior de veracidade e tecnicidade do que aquele que pode ser exigido de cidadãos comuns. Seria o reconhecimento de um dever democrático de embasar a sua fala e as suas condutas em informações técnicas, produzidas a partir de processos metodológicos minimamente consistentes." (BARROSO, Luna Van Brussel. Mentiras, equívocos e liberdade de expressão| JOTA Info.) 50 "No cenário atual, as mentiras criadas pelo uso de artifícios fraudulentos têm se tornado cada vez mais críveis e ameaçadoras às aspirações democráticas. Elas se tornam virais em espaço de tempo surpreendentemente curto e, por motivos ainda investigados pela neurociência, se espalham mais rápido do que as verdades, porque são mais apelativas." (BARROSO. Mentiras, equívocos e liberdade de expressão, op. cit.)

${ }^{51}$ Cotada para CCJ, Bia Kicis critica uso de máscaras e é investigada no STF por atos antidemocráticos. G1.

52 Conforme reza o caput do art. $6^{\circ}$ da CF/1988: "São direitos sociais a educação, a saúde, a alimentação, o trabalho, a moradia, o transporte, o lazer, a segurança, a previdência social, a proteção à maternidade e à infância, a assistência aos desamparados, na forma desta Constituição."
} 
o espaço virtual brasileiro. Mesmo lutando contra algumas turbulências próprias da "infomaré", discursos de valorização dos pressupostos da Lei Maior cumprem, brilhantemente, a árdua tarefa de cultivar - a cada "post", "live" ou "tweet" - a virtude democrática brasileira.

3.2. O aceno ao sentimento constitucional promovido pela divulgação de valores inerentes ao ordenamento

“Em tempos de crise politica e social, (...) há que se proteger e apostar ainda mais uma vez na Constituição.”

WALLACE CORBO.

Sem dúvidas, o cataclismo biológico despertado pela pandemia de Covid-19 reforçou a "frequência com que as normas da Constituição são invocadas nos mais diversos ambientes" $"$. Nesse sentido, podemos afirmar que o sentimento constitucional desperta, antes de tudo, o ato de "tratar a Constituição como coisa própria", na medida em que os valores contidos na Carta servem de norte para as ações externas do indivíduo situado politicamente e, em especial, virtualmente. A intrusão de valores constitucionais na Web oxigena uma democracia que enxerga na internet uma forma poderosa de fortalecimento dos valores contidos em seu escopo.

A partir disso, um dos principais reflexos da pandemia no cosmos virtual foi a ida dos profissionais da saúde para as redes sociais. A divulgação científica no molde online passou a ser imprescindível no combate às fake news ${ }^{54}$ referentes à pandemia: uma das linhas de frente dos cientistas teve que passar pela mobilização digital ${ }^{55}$, a partir de um instinto cidadão autêntico e genuíno. Liderando correntes de incentivo ao uso de máscaras ${ }^{56}$, de

\footnotetext{
53 BARROSO, Luís Roberto. Curso de Direito Constitucional Contemporâneo. 9. ed. São Paulo: Saraiva Educação, 2020, p. 482.

54 “Estamos, portanto, perante uma peculiar sobreposição de conflitos desencadeados por um discurso público radicalizado e fragmentado, onde os confins entre propaganda, alteração da realidade, conhecimento estabelecido e invenção de factos parecem evaporar-se, desafiando uma construção da realidade baseada em notícias e comentários virais, constantemente percepcionados como suspeitos e acusados de serem manipulados." (BALDI. A construção viral da realidade, cit., p. 10.)

${ }^{55}$ Destaco a iniciativa fundamental do jornalismo científico que se fez presente nas redes sociais. A postura de Luiza Caires, ao promover um debate no seu Twitter sobre "Cientistas \& Redes Sociais", ilustra bem o fenômeno da divulgação científica na internet brasileira. A pesquisadora também divulgou em seu perfil uma "newsletter" sobre seleção dos principais assuntos e conversas de ciência nas redes sociais". V. Twitter. Disponível em: <https://twitter.com/luizacaires3/status/1397561160749223936?s=20>. Acesso em: 27 de Maio de 2021.

${ }^{56}$ Destaco o papel do perfil "Qual Máscara”, idealizado pela antropóloga Beatriz Klimeck e pelo fotógrafo Ralph Holzmann. A campanha "PFF2 para todos" tem agitado as redes sociais, estimulando a proteção dos seguidores.
} 
reforço à necessidade de isolamento, de importância da vacinação e de valorização da ciência, muitos pesquisadores ${ }^{57}$ renomados conquistaram, graças ao seu ofício, a posição de influenciadores da opinião pública. Nos veículos tradicionais, Margareth Dalcolmo, Natália Pasternak, Átila Iamarino, Dimas Covas, Denise Garrett, Pedro Hallal e Miguel Nicolelis são alguns dos nomes mais citados como referências confiáveis para um combate consciente da pandemia: os profissionais compatibilizaram, a duras penas, as suas respectivas metodologias com a tutela geral da dignidade da pessoa humana ${ }^{58}$, um dos corolários da Lei Maior.

O delineamento de um sentimento constitucional - ainda que implicitamente expresso na conduta de tais personalidades - promove, sem embargo, uma conscientização dos cidadãos ${ }^{59}$ : os sujeitos passam a realizar o seu papel decisivo - enquanto seres políticos ligados à coletividade - na contenção da enfermidade que ameaça o seu entorno. Se a estratégia da gestão federal demonstrou ser ineficiente e incapaz de intervir positivamente no colapso sanitário, vários cientistas buscaram amenizar os estragos e suprir as lacunas do poder público na divulgação de informações essenciais para a saúde coletiva. Nesse contexto, artigos, entrevistas e matérias - que contém em si uma verificabilidade - acabam, mesmo que mediatamente, contribuindo para a conformação de um patamar de concretização dos direitos fundamentais, ratificando a postura de "prazer" e complacência frente ao sentimento constitucional.

\title{
4 Considerações finais
}

\author{
"salvo engano o futuro não se imprime \\ como o passado nas pedras nos móveis no rosto" \\ ANA MARTINS MARQUES, O Livro das Semelhanças.
}

\footnotetext{
${ }^{57}$ Conforme dispõe o caput do art. 2018 da CF/1988: “O Estado promoverá e incentivará o desenvolvimento científico, a pesquisa, a capacitação científica e tecnológica e a inovação."

${ }^{58}$ Em consonância com inciso III do art. $1^{\circ}$ da CF/1988: “Art. $1^{\circ}$ A República Federativa do Brasil, formada pela união indissolúvel dos Estados e Municípios e do Distrito Federal, constitui-se em Estado Democrático de Direito e tem como fundamentos: III - a dignidade da pessoa humana;"

59 "Uma cidadania ativa não pode, portanto, supor a ausência de uma vinculação normativa entre Estado de Direito e democracia. Ao contrário, quando os cidadãos vêem a si próprios não apenas como os destinatários, mas também como os autores do seu direito, eles se reconhecem como membros livres e iguais de uma comunidade jurídica. Daí a estreita conexão entre a plena autonomia do cidadão, tanto pública quanto privada, e a legitimidade do direito. (...) quanto mais conscientes forem os indivíduos, menos facilmente serão motivados por interesses particulares. De tal sorte, a construção da cidadania rege-se pelos anseios da população inseridos em um contexto dinâmico de integração, jamais de exclusão, vez que interessa ao fortalecimento da nação a participação de todos na construção dos sustentáculos do Estado. Assim, admitida a efetiva inclusão dos destinatários na conformação do ordenamento jurídico constitucional (...).” (VIEIRA. A importância do sentimento constitucional como substrato para a construção da cidadania no Brasil, cit., p. 7-8)
} 
O imbricamento entre Direito, democracia e política passou a adquirir novas proporções a partir do advento da globalização e, posteriormente, a partir do fortalecimento da Revolução Tecnológica. Os novos dilemas lançados sobre o futuro avolumam-se a cada dia. Paralelamente a esse processo, a emergência da pandemia de Covid-19 não restringiu seus desafios somente às áreas médicas e biológicas: as ciências sociais devem, no mais tardar, abandonar a construção de saberes departamentalizados, com vistas a encontrar na interdisciplinaridade ${ }^{60}$ caminhos, alternativas e soluções que se adequem à "economia do conhecimento".

No presente estudo, a noção de "sentimento constitucional" foi encarada como uma ferramenta imprescindível no processo de “(...) desenvolvimento de uma nova ética, não apenas transnacional, mas transgeracional", que possa, por seu turno, "aditar rumos para todo o Direito" ${ }^{\prime 61}$. A dinamicidade das forças sociais ${ }^{62}$ exerce uma pressão crescente sobre o Direito para que, a passos largos, as normas incorporem a instantaneidade própria dos nossos tempos. No fundo, tal demanda sobre o universo jurídico põe em xeque o dogma da completude do ordenamento: o Direito, frente à era 4.0, terá de reconhecer que os problemas contemporâneos não encontram uma resposta pronta e pré-fabricada, tal qual se opera na lógica binária “zero-um”. Imersos na cultura do conhecimento, os operadores devem manejar o seu cabedal teórico com o fito de encontrar soluções inovadoras, que não sacrifiquem a segurança jurídica - sobretudo quando direitos fundamentais ${ }^{63}$ incidirem sobre o caso concreto. Nesse ínterim, o sentimento constitucional deve ser posto sempre em um local de destaque: afinal de contas, manter vívido o "sentir jurídico" reafirma continuamente o triunfo da neoconstitucionalização do direito, corrente responsável por célebres conquistas civilizatórias.

\footnotetext{
60 "Ciência do Direito precisa estabelecer novos e chegados contatos com as Ciências Sociais, superando-se a formação jurídica departamentalizada." (BOBBIO, Norberto. Teoria do ordenamento jurídico. São Paulo: Polis. Brasília: Editora Universidade de Brasília, 1989. Apresentação de Tércio Sampaio Ferraz Júnior.)

${ }^{61}$ MOREIRA NETO. O Direito Administrativo no Século XXI. cit., p. 187.

62 "A gramática das relações sociais, no cenário info-comunicacional pouco estruturado e racional, apresentase sob forma de contrastes polarizados entre grupos e/ou indivíduos que expressam sobre a mesma realidade interpretações muito diferentes ou, para utilizar um termo mais emblemático da atual semântica histórica, concepções da realidade "alternativas" e inconciliáveis, como se a realidade fosse algo factualmente sempre menos interessante, acessório e secundário (Sunstein, 2017)." (BALDI. A construção viral da realidade, cit., p. 5.)

63 "É preciso (...) desenvolver uma teoria capaz de compatibilizar a liberdade dos cidadãos de expressarem a sua voz no debate público, sem, porém, sacrificar o conhecimento técnico e a veracidade de fatos." (BARROSO. Mentiras, equívocos e liberdade de expressão, op. cit.)
} 
Não obstante as transformações no universo jurídico, a cidadania e a responsabilidade social continuarão a sofrer mudanças derivadas da era da conectividade. Tais mudanças somente serão substantivas na medida do incremento do nível de educação dos cidadãos ${ }^{64}$, iniciativa de inegável importância para o aperfeiçoamento do sentimento constitucional comprometido com o Estado Democrático de Direito. De todo modo, se a democracia e a política já enfrentavam demandas inéditas graças à ampliação do acesso digital, a pandemia propiciou o surgimento de novos desafios: uma "democracia conectada" precisa reafirmar continuamente seus pactos constitucionais ${ }^{65}$, para que a essência valorativa da Carta Política não se perca em meio a uma profusão de tendências. Entre dados, algoritmos e bytes, o ciberespaço - que passou a ser uma morada constante desde meados de 2020 - deve comportar saudações democráticas, a fim de que se opere um acontecer constitucional transposto para um ambiente virtual ${ }^{66}$.

No fim do dia, a tarefa árdua de tentar acomodar um tema complexo em poucas páginas proporcionou, ao final, mais questionamentos do que respostas: no fundo, a intenção inicial não era desatar nós nem tampouco desenhar relações taxativas de causa e efeito. Para além da abstração inerente ao conceito de "sentimento constitucional", a análise de um processo ainda em curso - como é o caso da pandemia - não comporta a retirada de conclusões maduras e consistentes metodologicamente. O recorte proposto no trabalho entra em confronto com a velocidade das transformações que, a todo momento, atualizam as tendências observadas no estado de crise atual. A despeito desse pequeno ensaio poder não ter honrado o título a ele conferido, as ideias aqui expostas tentam, ao menos, resgatar uma criticidade indispensável à construção de saberes robustos.

\footnotetext{
64““(...) se quisermos manter instituições democráticas sólidas e à prova de narrativas falaciosas, é fundamental promover, desde cedo, entre os jovens, letramento midiático e educação para uma cidadania informada e consciente." (COSTIN, Cláudia. Democracia, populismo e verdade. Folha de São Paulo. São Paulo: 28 de outubro de 2021. Jornalismo. Disponível em: https://www1.folha.uol.com.br/colunas/claudiacostin/2021/10/democracia-populismo-e-verdade.shtml. Acesso em 01/11/2021)

65 "Do ponto de vista político, o mundo é testemunha da recente ascensão de governos populistas, cuja agenda parte invariavelmente de uma pauta bastante simplista, com ações que revelam baixa capacidade analítica sobre os verdadeiros desafios contemporâneos." (TEIXEIRA; SPAREMBERGER. Da Sociedade do Cansaço à Sociedade da Vigilância, cit., p. 37.)

66 '“(...) a pandemia revela antes do tempo, antecipadamente, a verdade da digitalização galopante de nossos meios de comunicação, formas de trabalhar e nos relacionarmos, que é o controle de dados e dos seus portadores para assim melhor explorá-los em suposto benefício próprio, isolando-(n)os ainda mais. Eis como se exerce agora mais imediatamente o chamado biopoder, agora biodigital, sendo o soberano (...) quem dispõe sobre os dados." (MELO. Covid-19 e Direito Brasileiro, cit., p 16.)
} 


\section{Referências Bibliográficas}

¿Qué pasa con la extrema derecha online? | Nueva Sociedad. Nueva Sociedad | Democracia y política en América Latina. Disponível em: <https://nuso.org/podcast/que-pasa-conla-extrema-derechaonline/?utm_source=email\&utm_medium=email\&utm_campaign=email\&s=08>. Acesso em: 27 de Maio de 2021.

ADAMS, Luís Inácio. O discurso do ódio e a liberdade de expressão II: o caso do deputado Daniel Silveira. Consultor Jurídico. Disponível em: <https://www.conjur.com.br/2021-fev-22/publico-privado-discurso-odio-liberdadeexpressao-ii-deputado-daniel-silveira>. Acesso em: 27 de Maio de 2021.

AGÊNCIA ESTADO. YouTube remove vídeo de deputada Bia Kicis por desinformar sobre covid-19. Brasil. Disponível em: <https://www.correiobraziliense.com.br/brasil/2021/03/4910621-youtube-removevideo-de-deputada-bia-kicis-por-desinformar-sobre-covid-19.html>. Acesso em: 27 de maio de 2021.

BALDI, Vania. A construção viral da realidade: ciberpopulismos e polarização dos públicos em rede. Observatório (OBS*) Special Issue, (2018), 004-020.

BARROSO, Luís Roberto. Curso de Direito Constitucional Contemporâneo. 9. ed. São Paulo: Saraiva Educação, 2020. 576 p.

. Direito e Paixão. Revista da Faculdade de Direito da Universidade do Estado do Rio de Janeiro. n. 2, p. 321-338, 1994.

Neoconstitucionalismo e constitucionalização do Direito (O triunfo tardio do direito constitucional no Brasil). Revista de Direito Administrativo, v. 240, p. 1-42, 1 abr. 2005.

Sem data venia: um olhar sobre o mundo e sobre o Brasil. 1. ed. Rio de Janeiro: História Real, 2020.

BARROSO, Luna Van Brussel. Mentiras, equívocos e liberdade de expressão | JOTA Info. Disponível em: <https://www.jota.info/coberturas-especiais/liberdade-deexpressao/mentiras-equivocos-e-liberdade-de-expressao-

29052020\#sdendnote8sym>. Acesso em: 27 de Maio de 2021.

- Recessão democrática, populismo e um papel possível para as cortes constitucionais. Mimeografado, 2019.

Luna van Brussel Barroso: A democracia e a liberdade de expressão | Fumus boni iuris - O Globo. Disponível em: <https://blogs.oglobo.globo.com/fumus-boniiuris/post/luna-van-brussel-barroso-democracia-e-liberdade-de-expressao.html > Acesso em: 27 de Maio de 2021.

BOBBIO, Norberto. Teoria do ordenamento jurídico. São Paulo: Polis. Brasília: Editora Universidade de Brasília, 1989. Apresentação de Tércio Sampaio Ferraz Júnior.

BRASIL. Constituição (1988). Constituição da República Federativa do Brasil. Brasília, DF: Senado Federal: Centro Gráfico, 1988.

CORBO, Wallace. Filosofia Constitucional e Teoria do Reconhecimento: entre o Direito Constitucional ao Reconhecimento e o Constitucionalismo do Reconhecimento. Revista da Faculdade de Direito do Sul de Minas, Pouso Alegre, v. 34, n. 1: 1-35, jan./jun. 2018.

COSTIN, Cláudia. Democracia, populismo e verdade. Folha de São Paulo. São Paulo: 28 de outubro de 2021. Jornalismo. Disponível em: https://www1.folha.uol.com.br/colunas/claudia-costin/2021/10/democraciapopulismo-e-verdade.shtml. Acesso em 01/11/2021. 
Cotada para CCJ, Bia Kicis critica uso de máscaras e é investigada no STF por atos antidemocráticos. G1. Disponível em: <https://g1.globo.com/politica/noticia/2021/02/03/cotada-para-a-ccj-bia-kicis-einvestigada-por-atos-antidemocraticos-e-critica-uso-de-mascaras-contra-a-covid19.ghtml>. Acesso em: 27 de maio de 2021.

COUTINHO, Fábio de Sousa. Leituras de Direito Político. 1. ed. Brasília: Thesaurus, 2004. $227 \mathrm{p}$.

Especialistas questionam tentativa de dificultar retirada de conteúdo das redes. Consultor Jurídico. Disponível em: <https://www.conjur.com.br/2021-mai-23/especialistascriticam-tentativa-bolsonaro-controlar-redes-sociais>. Acesso em: 28 de Maio de 2021.

HERVADA, Javier. O que é o direito? A moderna resposta do realismo jurídico. 1.ed. São Paulo: WMF Ed. Martins Fontes, 2006. Tradução de Sandra Martha Dolinsky.

MAGRANI, Eduardo. Democracia conectada: a internet como ferramenta de engajamento político-democrático. Curitiba: Juruá, 2014. 222p.

MAYARA, Jéssica. Brasileiros têm mais acesso à internet, TV e smartphone; confira. Estado de Minas. Disponível em: <https://www.em.com.br/app/noticia/tecnologia/2021/04/15/interna_tecnologia,1257 304/brasileiros-tem-mais-acesso-a-internet-tv-e-smartphone-confira.shtml>. Acesso em: 27 de Maio de 2021.

MELO, Ezilda; BORGES, Lize; SERAU JR., Marco Aurélio (Orgs.). Covid-19 e Direito Brasileiro: mudanças e impactos. 1. ed. São Paulo: Tirant lo Branch, 2020.

MOREIRA, Nelson Camatta. Fundamentos de uma teoria da constituição dirigente. Santa Catarina: Conceito, 2010. p. 201-202.

MOREIRA NETO, Diogo de Figueiredo. O Direito Administrativo no Século XXI. Belo Horizonte: Fórum, 2018.

NASCIMENTO, Valéria Ribas do; MORAIS, José Luiz Bolzan de. A cidadania e a Constituição: Uma necessária relação simbólica. Revista de Informação Legislativa, Brasília a. 44 n. 175 jul./set. 2007.

TEIXEIRA; SPAREMBERGER. Da Sociedade do Cansaço à Sociedade da Vigilância: entre utopias e distopias, o direito à privacidade no contexto pós-pandemia. In: MELO, Ezilda; BORGES, Lize; SERAU JR., Marco Aurélio (Orgs.). Covid-19 e Direito Brasileiro: mudanças e impactos. 1. ed. São Paulo: Tirant lo Branch, 2020.

VARGAS, Matheus. Bolsonaro prepara decreto, considerado ilegal, para limitar retirada de posts e perfis das redes sociais. Folha de S. Paulo. Disponível em: $<$ https://www1.folha.uol.com.br/poder/2021/05/governo-prepara-decreto-paralimitar-retirada-de-posts-e-perfis-das-redes-sociais.shtml?origin=folha $>$. Acesso em: 28 de Maio de 2021.

VERDÚ, Pablo Lucas. O sentimento constitucional: aproximações ao estudo do sentir constitucional como modo de integração política. Tradução de Agassiz Almeida Filho. Rio de Janeiro: Forense, 2004.

VERGOTTINI, Giuseppe de. 2004: verbete "Constituição", in Norberto BOBBIO, Nicola MATTEUCCI \& Gianfranco PASQUINO: Dicionário de Política, UnB, Brasília.

VIEIRA, Andréa Maria dos Santos Santana. A importância do sentimento constitucional como substrato para a construção da cidadania no Brasil. Derecho y Cambio Social. n. 31. 01 de jan. de 2013. Disponível em: <http://www.derechoycambiosocial.com/revista031/do_sentimento_constitucional.pd f>. Acesso em 27 de maio de 2021. 
VIEIRA, Iacyr de Aguilar. A essência da Constituição no pensamento de Lassalle e de Konrad Hesse. Revista de Informação Legislativa. Brasília a. 35 n. 139 jul./set. 1998. XI ENCONTRO DE ADVOGADOS, 1982, Garanhuns, Pernambuco. A Legitimidade do Poder Público na Experiência Brasileira. 30p. 
Como citar este artigo: GUIMARÃES, Sofia Seabra Fagundes de Q. O sentimento constitucional brasileiro em meio à pandemia; Como a era informatizada reformulou o debate público e suscitou discussões sobre predicados estatais diante da calamidade sanitária atual?. Revista de Ciências do Estado, Belo Horizonte, v. 6, n. 2, p. 1-22, 2021.

Recebido em 07.09.2021

Publicado em 16.12.2021

(cc) EY-Nc-sa Atribuição-NãoComercial-CompartilhaIgual 4.0 Internacional 